\title{
FIRST REPORT OF GROUNDWATER FAUNA FROM PAPUA NEW GUINEA: KINNECARIS JAKOBI, 1972 REDEFINED (COPEPODA, HARPACTICOIDA, PARASTENOCARIDIDAE), AND DESCRIPTION OF A NEW SPECIES
}

\author{
BY
}

\author{
HORST KURT SCHMINKE ${ }^{1}$ ) \\ Institut für Biologie und Umweltwissenschaften, Fakultät V, Universität Oldenburg, \\ Postfach 2503, D-26111 Oldenburg, Germany
}

\begin{abstract}
The groundwater fauna of Papua New Guinea is completely unknown. The first member of this fauna is reported here. It is a new species of Parastenocarididae that agrees in eleven characters with 16 known species. Of these characters at least one (the powerful, prehensile antennule of the male) can be regarded as an autapomorphy of this group of species. Likewise, the arrangement of setae on the furcal rami and the conspicuous triangular and plate-like fifth leg may qualify as such. Two of Jakobi's (1972) genera have type species that fall into this particular group of species, viz., Kinnecaris and Cafferocaris. Cafferocaris is synonymized here with Kinnecaris, which is a monophylum including not only the type species $K$. forficulata but also 15 additional species, together with the new one from Papua New Guinea, Kinnecaris giselae sp. n. The genus Kinnecaris Jakobi, 1972 is redefined. Its species occur all along the eastern side of Africa from Ethiopia down to South Africa, but also in West Africa. Others are known from Madagascar, India, Western Australia, and Papua New Guinea.
\end{abstract}

\section{ZUSAMMENFASSUNG}

Die Grundwasserfauna Papua Neuguineas ist völlig unerforscht. Ein erster Vertreter dieser Fauna wird hier vorgestellt. Es handelt sich um eine neue Art der Parastenocarididae, die in elf Merkmalen mit 16 bekannten Arten übereinstimmt. Zumindest eines dieser Merkmale (die kräftig prähensile Antennula des Männchens) kann als mögliche Autapomorphie der Artengruppe betrachtet werden. Auch die Anordnung der Borsten auf den Furkalästen und die auffälligen, dreieckigen und plattenähnlichen 5. Beine könnten als solche in Frage kommen. Zwei von Jakobis (1972) Gattungen haben Typusarten, die zu dieser Artengruppe gehören, nämlich Kinnecaris und Cafferocaris. Cafferocaris wird hier mit Kinnecaris synonymisiert, die als ein Monophylum neben der Typusart K. forficulata 15 weitere Arten und die neue aus Papua Neuguinea, Kinnecaris giselae sp. n., umfasst. Die Gattung Kinnecaris Jakobi, 1972 wird neu definiert. Ihre Arten kommen entlang der gesamten Ostseite Afrikas von Äthiopien bis hinunter nach Südafrika, aber auch in Westafrika vor. Weitere Arten sind von Madagaskar, aus Indien, Westaustralien und Papua Neuguinea bekannt.

\footnotetext{
1) e-mail: schminke@uni-oldenburg.de

(C) Koninklijke Brill NV, Leiden, 2008

Crustaceana 81 (10): 1241-1253

Also available online: www.brill.nl/cr 


\section{INTRODUCTION}

Parastenocarididae belong to the most species-rich taxa within Harpacticoida. To date, some 260 species are known from groundwater around the world with the notable exceptions of New Zealand and the Caribbean Islands. About 200 of these species belong to the genus Parastenocaris Kessler, 1913, whereas the rest is grouped into six additional genera. Thus, it can be assumed that Parastenocaris is not monophyletic. Apart from these accepted genera there are 22 additional ones, which had been proposed by Jakobi (1972). Formally, all of them are valid, yet they are not as clearly defined as would have been necessary to unambiguously assign new species to them.

Before Jakobi (1972), species had been united into species-groups. Chappuis (1937) was the first to distinguish such groups, followed by Kunz (1938). The most comprehensive grouping, however, was proposed by Lang (1948) who distinguished eight groups: the proserpina-group Kunz, the brevipes-group Lang, the minuta-group Lang, the nana-group Lang, the clujensis-group Lang, the muscicola-group Lang, the fontinalis-group Lang, and the staheli-group Lang. Later, further groups have been added: the panamericana-group (Noodt, 1962), the sioligroup, the remanei-group, the forficata-group (Noodt, 1963), the columbiensisgroup (Noodt, 1972), the hera-group (Berera \& Cottarelli, 2003), and the vandeli-group (Galassi \& De Laurentiis, 2004). Despite Jakobi's (1972) system, those species-groups that have not been raised to genus-rank in the meantime, are still used today when it comes to classifying new species. No doubt, Jakobi's (1972) system needs thorough revision.

The first revisionary steps towards an ultimate phylogenetic analysis have already been made. Galassi \& De Laurentiis (2004) introduce the genus Simplicaris, profiting from the detailed redescription of the type species, Parastenocaris brevipes Kessler, 1913 by Reid (1995), who suggests to restrict the genus Parastenocaris to the species of the brevipes-group only. So, all other species need be placed into other genera. This, however, raises the problem of Jakobi's (1972) genera. Revision of Parastenocarididae thus requires their redefinition. Corgosinho \& Martínez Arbizu (2005) have gone ahead by redefining Remaneicaris Jakobi, 1972 and by demonstrating its monophyletic nature. The present contribution is another attempt at redefining one of Jakobi's genera. This is an elaboration of ideas already presented by Schminke in 1986. The discovery in Papua New Guinea of a new species of this genus has made this redefinition necessary.

\section{MATERIAL AND METHODS}

Samples were collected by digging a pit on the bank of the River Sivogana. The water accumulating on the bottom of the pit was filtered through a plankton 
net (mesh $70 \mu \mathrm{m})$ and the residue fixed in 5\% formaldehyde. Specimens were later transferred to a drop of the medium W15 (Zeiss) and mounted on slides. Microscopic investigation was carried out with a Leica interference microscope (DMLB with UCA condenser, IC prism, and doublers $\times 1.5$ and $\times 2$ ). Drawings were made with the DMLB microscope and with the aid of a drawing tube (mirror technique and macro-apparatus FS25PE).

\section{SYSTEMATICS}

Kinnecaris giselae sp. n. (figs. 1-3)

Etymology. - This species is dedicated to the memory of my wife, Dr. Gisela Schminke, who accompanied and helped me during eight exciting weeks of collecting in Papua New Guinea.

Type locality and material examined. - Kinnecaris giselae sp. $\mathrm{n}$. is described from the hyporheic zone of the Sivogana River. Sample PNG 4 was taken on 6 October, 1984 on the bank of the river where it makes a bend near the road from Kupiano to Port Moresby (direction Kwikila) 1 to $1.5 \mathrm{~km}$ before Imairu Bridge. Two pits of $75 \mathrm{~cm}$ depth were dug in coarse gravel mixed with coarse sand at a distance of $8.5 \mathrm{~m}$ and $4.0 \mathrm{~m}$ from the river's edge. The temperature of the water in the pit was $27.8^{\circ} \mathrm{C}$, that of the river water $26.5^{\circ} \mathrm{C}$.

Holotype male (dissected on 4 slides, catalogue no. SMF 32216), allotype female (dissected on 4 slides, catalogue no. SMF 32217), one paratype male (undissected on 1 slide, catalogue no. SMF 32218), 2 paratype females (undissected on one slide, catalogue no. 32219) are kept in the collection of the Deutsches Zentrum für Marine Biodiversitätsforschung (DZMB) at Wilhelmshaven (Germany), being a department of the Senckenberg Museum und Forschungsinstitut, Frankfurt am Main (SMF).

Description of adult male (holotype). - Total body length of holotype, measured from rostrum to posterior margin of anal operculum $251 \mu \mathrm{m}$. Body slender, about 9 times as long as wide. Cuticle perforated by innumerable pits (fig. 1A). Cephalothorax with integumental double-window. Urosomal somites 4 and 5 with paired lateral elliptical integumental windows, which are slightly smaller on urosomal somite 4 than on somite 5 (the latter in lateral view also a little more ventral than those of somite 4) (fig. 1A). Urosomal somite 3 with two groups of 4 spinules ventrally (fig. $3 \mathrm{~A}$ ). Anal operculum rounded and smooth, not reaching beyond end of anal somite (fig. 1C).

Caudal rami (fig. 1C) symmetrical, slightly divergent and almost half the length of the anal somite. Each ramus 3.2 times as long as its maximum width; at $2 / 3$ of the ramus' length with lateral group of 3 setae that are unequal in length; dorsal seta located opposite to the 3 lateral setae and biarticulate at base, posterolateral seta longer than inner terminal one, which is not really terminal but shifted more proximally to the ventral side of the ramus.

Rostrum with pair of dorsolateral sensilla. 


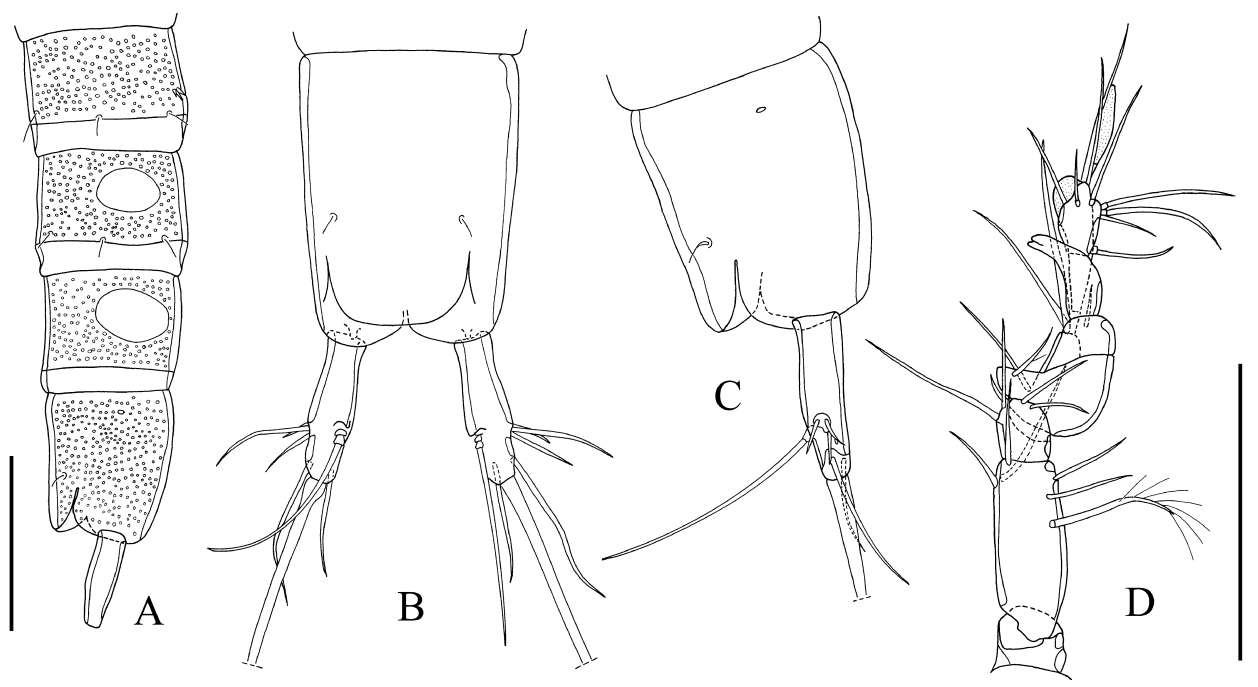

Fig. 1. Kinnecaris giselae sp. n. A, urosome, lateral view (male paratype); B, anal somite and furca, dorsal view (female allotype); $\mathrm{C}$, anal somite and furca, lateral view (male paratype); $\mathrm{D}$, antennule, dorsal view (male holotype). Scale bars, $50 \mu \mathrm{m}$.

Antennule (fig. 1D) 8-segmented; segments 1 and 7 without spinules. Segment 2 longest. Segment 4 a small sclerite; segment 5 much dilated, with proximally a powerful inner conical protrusion; segment 7 sickle-shaped, terminally with a notch. Setation formula: 0/6/4/2/4+aes/1/0/9+aes. Aesthetasc on segment 5 club-shaped, broadening terminally and reaching end of antennule; aesthetasc on segment 8 slender and short.

Antenna identical with that of Kinnecaris eberhardi (Karanovic, 2005) (cf. Karanovic, 2005, fig. 4).

Mouthparts as described for Parastenocaris inferna Schminke, 1971 by Schminke (1971, fig. 1).

Leg 1 (fig. 2A) with bare coxa. Basis with no outer seta and with spinule rows on outer and inner margins as well as at base of endopod. Exopod 3-segmented and slightly shorter than endopod; first segment with 1 bare outer spine and 3 spinule rows on outer margin; second and third segments together as long as first segment; no outer spine on second segment but with distal spinule row on outer margin; third segment with 2 unipinnate outer spines, 2 geniculate and unipinnate, apical setae and with a distal spinule row on outer margin. Endopod 2-segmented; first segment as long as first two segments of exopod together, with 2 spinule rows on outer margin and 1 row on inner margin; second segment half as long as first one, with 1 unipinnate outer spine, 1 unipinnate geniculate terminal seta, and with 1 spinule row on outer margin and 1 transverse row on inner margin. 


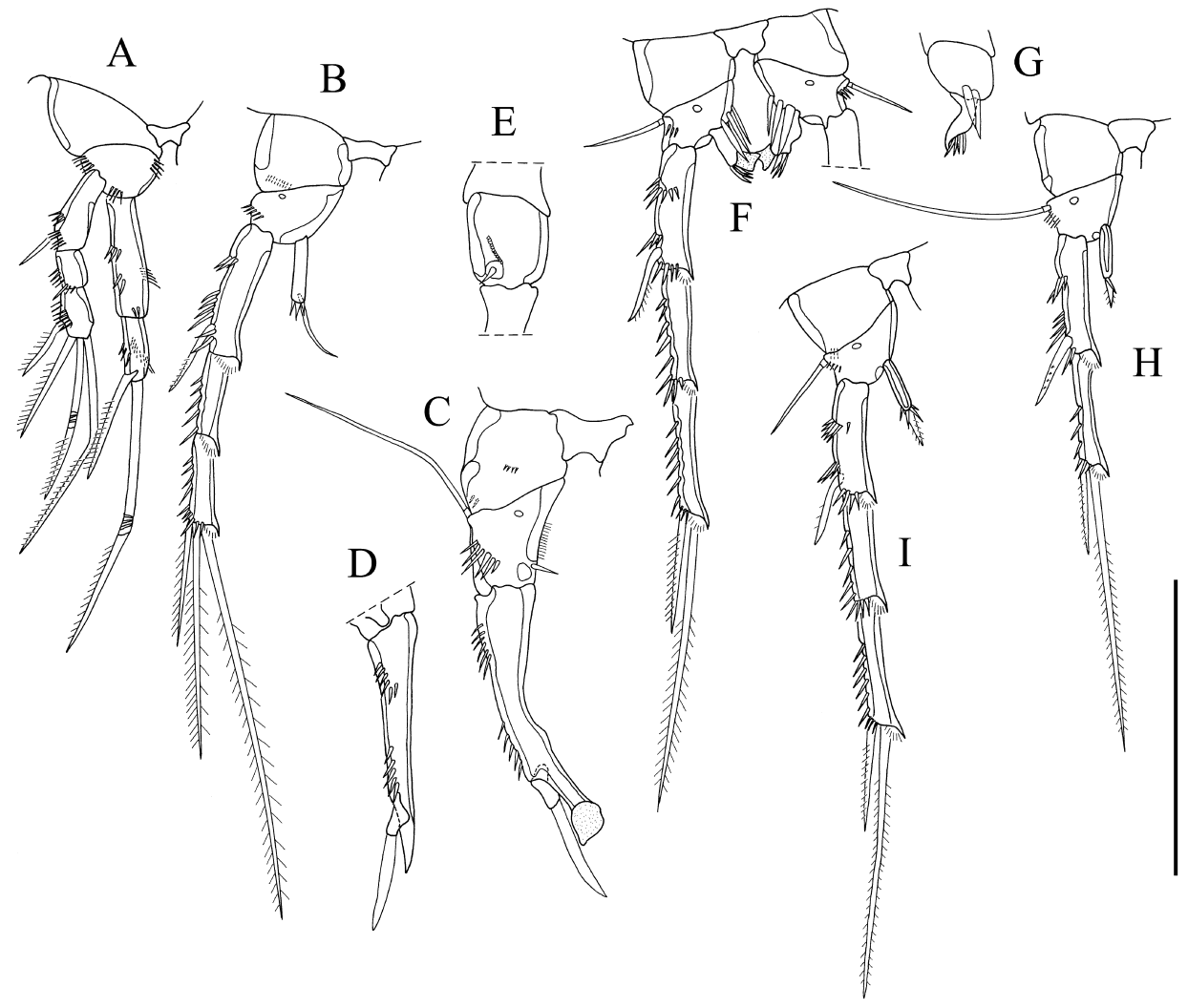

Fig. 2. Kinnecaris giselae sp. n. A, leg 1; B, leg 2; C, leg 3 (all male holotype); D, exopod of leg 3, lateral view; E, basis of leg 3, internal view (both male paratype); F, leg 4 (male holotype); G, basis of leg 4, internal view (male paratype); H, leg 3; I leg 4 (both female allotype). Scale bar, $50 \mu \mathrm{m}$.

Leg 2 (fig. 2B) with spinule row on coxa. Basis with pore and a spinule row on outer margin, but without outer seta. Exopod 3-segmented; first segment $45 \%$ of total length of exopod; other two segments almost equal in length; first segment with unipinnate outer spine and 2 spinule rows on outer margin; second segment without spine, but with longitudinal row of spinules along outer margin; third segment with 2 pinnate terminal setae and 1 unipinnate outer one, and along outer margin with longitudinal row of spinules. Endopod 1-segmented, slender, rod-like, half as long as first segment of exopod, with apical row of 3 spinules and 1 inwardly curved seta.

Leg 3 (fig. 2C) with 2 short spinule rows on coxa. Basis with pore, strongly developed outer seta, and oblique row of 6 spinules running medially from outer margin; 1 short row of denticles at distal inner margin ending at short seta representing endopod (fig. 2E). Exopod 1-segmented, slightly incurved, with 2 rows of 6 (proximally) and 5 (distally) spinules along outer margin (fig. 2D); 


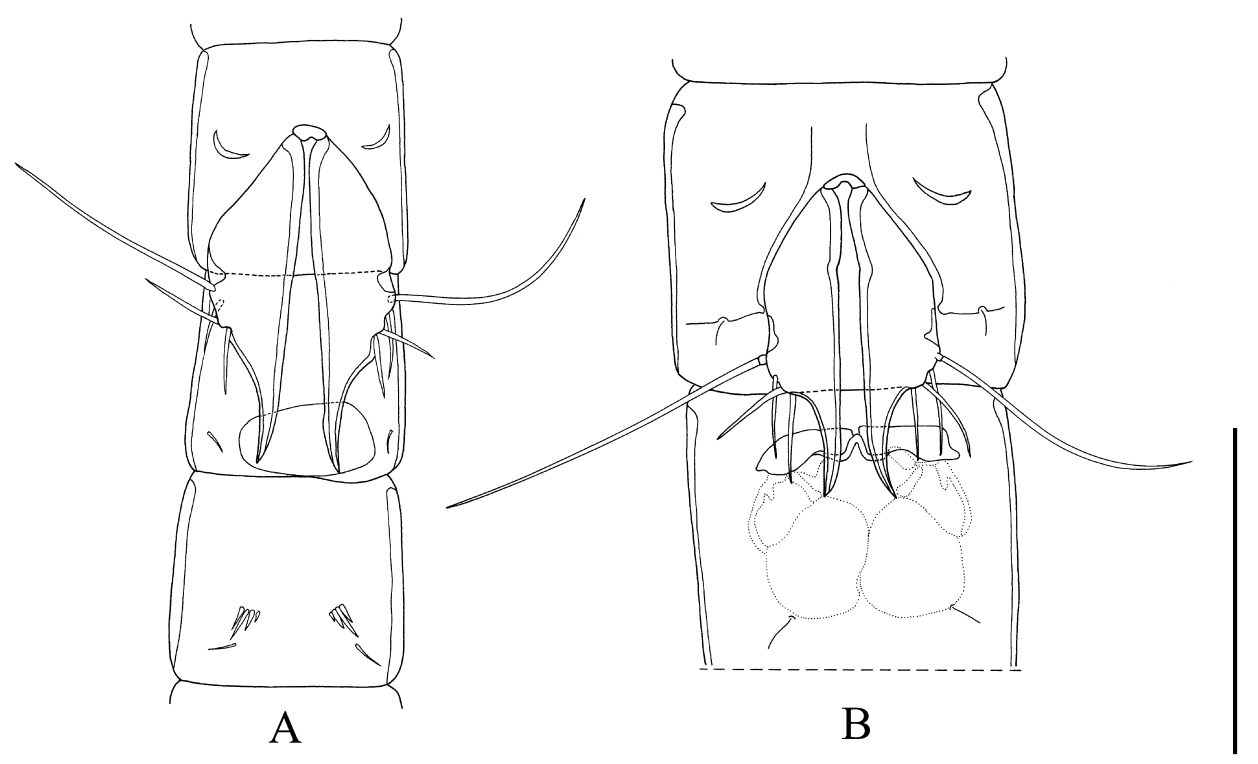

Fig. 3. Kinnecaris giselae sp. n. A, leg 5 and part of urosome, ventral view (male holotype); B, leg 5 and genital field, ventral view (female allotype). Scale bar, $50 \mu \mathrm{m}$.

apophysis straight, with round piece of membrane at its tip, being slightly less than one-third shorter than thumb, which has the form of a long knife with a short handle.

Leg 4 (fig. 2F, G) without ornamentation on coxa. Basis with pore, outer seta, and a short row of 3 small spinules at outer margin and of 3 large ones at base of endopod. Exopod much elongate; first two segments equal in length, third segment slightly longer; first segment with outer spine and 2 oblique spinule rows on outer margin and 1 spinule row distally; second and third segments with longitudinal row of spinules along outer margin; third segment additionally with unipinnate outer and bipinnate apical seta. Endopod 1-segmented, short, rectangular, obliquely directed inwards, with 3-4 spinules and 1 short membrane terminally.

Leg 5 (fig. 3A) strongly developed, simple triangular plate, with inner distal corner drawn out into massive, pointed, outwardly curved, spinous process, reaching almost end of following segment; armature consisting of very long outer basal seta and 3 additional small setae along outer margin, of which the middle one is the longest, no spinules along inner margin; intercoxal plate arch-like.

Description of adult female (allotype). - Total body length of allotype, measured from rostrum to posterior margin of anal operculum $312 \mu \mathrm{m}$. Cuticle, integumental windows, caudal rami, antenna, leg 1 , leg 2 , and leg 5 as in male. Genital field as in fig. 3B. Urosomal somite 2/3 (double somite) without spinules ventrally (fig. 3B). 
Antennule 7-segmented. Segment 1 with 1 ventral row of spinules. Segment 2 longest. Segments 1-7 with 0, 4 (1 unipinnate), 4, 2, 1, 1, and 9 setae, respectively. Segments 4 and 7 each with aesthetasc, that on segment 4 reaching only to half of the terminal segment; that on segment 7 relatively short and acicular.

Leg 3 (fig. 2H) with bare coxa. Basis with pore, long outer seta, and spinule row at outer margin. Exopod 2-segmented, both segments about equal in length; first segment with 1 spine at outer distal corner, 2 spinule rows at outer margin, and with a few spinules distally; second segment with spinules arranged longitudinally along outer margin and with 1 long apical seta and 1 outer spine, which is as long as that of the first segment. Endopod 1-segmented, a short rod with bipinnate apical seta and 1 apical spinule.

Leg 4 (fig. 2I) with short spinule row on coxa. Basis with pore, outer seta, and spinule row on outer margin. Exopod 3-segmented, third segment slightly longer than other two, which are about equal in length. Otherwise like in male. Endopod 1 -segmented, similar to that of female leg 3 except for 4 spinules apically instead of one.

The new species belongs to a few species in the genus in which the thumb of the male leg 3 is longer than the apophysis. Among these species, the new one is distinguished by its endopod leg 4 male, with terminal outer spinules and inner rectangular membrane.

\section{ECOLOGY}

At the type locality, the new species was found in good numbers. The fauna that co-occurred with it was diverse but not rich, and included the following: Ostracoda, Cyclopoida, other Harpacticoida, Amphipoda, Isopoda, and an elongate mite.

\section{DISCUSSION}

The groundwater fauna of Papua New Guinea is completely unexplored. This is the first report on a member of this fauna. The new species has many characteristic features in which it agrees with a number of other species. One of these features, are the plate-like, triangular 5th legs, which are so conspicuously spread apart and held downwards that they immediately attract the attention when looking at whole specimens. Both legs are extended posteriorly into long, outwardly-curved spiniform processes that are without spinules along their inner border. There is a small, arch-like intercoxal plate. The same leg 5 is found in the following species (in alphabetical order): Parastenocaris aethiopica Cottarelli \& Bruno, 1995; P. arenicola Chappuis, 1954; P. arenosus Fryer, 1956; P. caffer Chappuis, 1936; P. 
cornuta Chappuis, 1955; P. eberhardi Karanovic, 2005; P. fluviatilis Wells, 1964; P. forficulata Chappuis, 1952; P. impervia Cottarelli \& Bruno, 1995; P. lyncaea Cottarelli \& Bruno, 1994; P. madagascarensis Chappuis, 1952; P. muscicola Chappuis, 1936; P. quollensis Cottarelli \& Bruno, 1995; P. sinoiaica Wells, 1964; P. solitaria Karanovic, 2004; $P$. variolata Chappuis, 1952. Also leg 5 of the female of $P$. pusillus Chappuis, 1954 has to be mentioned, whereas leg 5 of that male is quite different. There is no sexual dimorphism in leg 5 of all other species of the group discussed here, so that it must be assumed that male and female of $P$. pusillus belong to different species.

Some authors have already recognized that some of the species listed above are rather similar. Lang (1948) united P. muscicola and P. caffer in his muscicolagroup. When describing $P$. variolata, Chappuis (1952) noticed its similarities with $P$. muscicola and $P$. caffer. Also $P$. forficulata was said to belong to this group. In his description of $P$. arenicola, Chappuis (1954) mentions its resemblance with $P$. variolata. Cottarelli \& Bruno (1994) point to the similarities of $P$. lyncaea with $P$. cornuta and $P$. sinoiaica. Finally, in his description of $P$. solitaria, Karanovic (2004) mentions 14 species because of their rather similar leg 5. Ten of those are also part of the list above. The remaining four in Karanovic's enumeration (P. aesculapii Cottarelli \& Bruno, 1997; P. christiani Dumont, 1981; P. monodi Chappuis, 1959; P. nigerianus Chappuis, 1959) differ not only in leg 5 but also in other characters.

Comparison of the new species from Papua New Guinea with the 16 species in our list above (excluding $P$. pusillus) reveals that there are 11 characters that they have in common. Because of incomplete descriptions, not all of these characters can be verified for all species, but it is considered highly likely that re-examination would bring them to light. These 11 characters are:

1. A pitted cuticle (fig. 1A).

2. Latero-ventral integumental windows on urosomal somites 4 and 5 (fig. 1A).

3. Two groups of spinules ventrally on urosomal somite 3 of the males (fig. 3A).

4. Furcal rami with lateral group of three setae located at $2 / 3$ of the ramus' length; dorsal seta also located there or inserted even more proximally (fig. 1B).

5. Antennule with much dilated fifth segment of which the proximal inner corner is extended into a large conical protrusion; the same is true for the distal inner corner of the seventh segment, which is extended into a strong, sickle-shaped bifid apophysis that like the blade of a pocket-knife can be folded back onto the fifth segment (fig. 1D). 
6. Endopod of leg 1 longer than exopod, first segment of endopod mostly longer than first two segments of exopod together (fig. 2A).

7. Spinules arranged longitudinally along outer border of exopodal segments 2 and 3 of leg 2 (fig. 2B) and leg 4 (fig. 2F) as well as of exopodal segment 2 of female leg 3 (fig. $2 \mathrm{H}$ ).

8. Outer terminal seta of third exopodal segment of leg 4 (fig. 2F) and of second exopodal segment of female leg 3 (fig. $2 \mathrm{H}$ ) remarkably shorter than inner terminal seta, in female leg 3 partly even shorter than seta at outer distal corner of first exopodal segment.

9. Exopod of leg 3 male (fig. 2C, D) with two longitudinal rows of spinules along outer border, one proximally, the other distally near insertion of thumb.

10. Basis of male leg 4 (fig. $2 \mathrm{~F}$ ) with a row of spinules above insertion of endopod.

11. Form and posture of male leg 5 (fig. 3A) and female leg 5 (fig. 3B) as described above, apart from basal outer seta with 3 additional small setae of which the middle one is the longest.

There are only three known species for which all of these characters are documented. These are: P. quollensis, $P$. eberhardi, and the new species from Papua New Guinea. (A new species from India can also be mentioned here, Kinnecaris sp. n. Ranga Reddy \& Schminke, submitted.) In the other species, various characters are either not mentioned, or not depicted or both. Let us have a look in detail.

Character 1: Cuticular pits shall lack in P. solitaria as is made explicit in the discussion in Karanovic (2005), also in P. arenicola of which Chappuis (1954) says: "Surface du corps lisse", and later when comparing $P$. arenicola with $P$. variolata he notes that "la surface du corps ne montre aucune sculpture". No mention at all of a pitted cuticle is made in the case of $P$. arenosus, $P$. aethiopica, $P$. fluviatilis, $P$. impervia, and $P$. sinoiaica, but at least in a redescription of $P$. arenosus by L. Fischer \& Th. Glatzel (in prep.) Fryer's (1956) oversight is corrected. A pitted cuticle is documented for the remaining 10 species of our list above.

Character 2: Lateral integumental windows are said by Chappuis (1952) to lack in $P$. variolata; they are not mentioned in the descriptions of $P$. arenicola, $P$. impervia, $P$. lyncaea, and P. muscicola; they are present in the remaining 12 species of the list above.

Character 3: The two groups of spinules on the urosomal somite 3 of the male are a character overlooked by most authors, but they are present in P. aethiopica, P. eberhardi, P. lyncaea, P. quollensis, and the new species from Papua New 
Guinea (and that from India). They are present also in $P$. arenosus as confirmed by L. Fischer \& Th. Glatzel (in prep.).

Character 4: The relationship in position between the lateral group of three setae and the dorsal seta of the furcal rami is documented for all species listed above.

Character 5: Descriptions of antennules are rare in the literature. Where they have been provided they confirm the strongly prehensile nature of them in those species that are of interest here. Massive pincers have been mentioned or depicted for $P$. aethiopica, $P$. cornuta, $P$. eberhardi, $P$. impervia, $P$. madagascarensis, $P$. $q u o l l e n s i s, P$. sinoiaica, and the new species from Papua New Guinea (and that from India). No mention of them is made for the remaining nine species, but the re-description of $P$. arenosus by L. Fischer \& Th. Glatzel (in prep.) proves them to be present also in that species.

Character 6: The length relationships between endopod and exopod of P1 are not always clear. There is no information for $P$. arenicola, $P$. cornuta, and $P$. variolata. In five species (P. aethiopica, $P$. impervia, P. lyncaea, $P$. quollensis, and $P$. sinoiaica) they appear to be of the same length, whereas in the remaining nine species not only the endopod is longer than the exopod but also the first segment of the endopod is longer than the first two segments of the exopod together.

Character 7: In the earlier descriptions of species no attention has been paid to this character but there are indications in the drawings. Thus it can be said that the longitudinal rows of spinules are present in all species except possibly in $P$. madagascarensis, for which there is no information. However, these rows are not documented for all three appendages (leg 2 , leg 4 , and female leg 3 ) in all cases.

Character 8: The outer terminal seta is very short in all species except possibly in $P$. arenicola and $P$. madagascarensis, for which there is no information. There are cases where there is only partial information, because the exopods were not drawn, presumably being regarded as of little taxonomic importance.

Character 9: The situation is clear in ten species. Nothing can be said for $P$. fluviatilis and $P$. solitaria, for lack of known males. There are no spinules in $P$. madagascarensis and in the case of $P$. arenicola, $P$. arenosus, $P$. cornuta, and $P$. forficulata only either the distal row, or the proximal one are shown in the figures. But in $P$. arenosus both rows are present, as revealed by the redescription by $\mathrm{L}$. Fischer \& Th. Glatzel (in prep.).

Character 10: The row of spinules on the basis of the male leg 4 is present in 11 species. Nothing can be said for $P$. fluviatilis and $P$. solitaria, for lack of known males. There is no indication of this row in the drawings of $P$. arenosus (confirmed by L. Fischer \& Th. Glatzel in prep.), P. caffer, P. muscicola, and $P$. variolata. Thus, it has to be assumed that the row has been lost secondarily in a few species.

Character 11: This character (leg 5) has already been dealt with above. 
The discussion has shown that there are many characters that the 17 species in question have in common. Not all of these characters have been documented for all species, but it can be expected that re-examination would reveal them (as is already the case with the redescription of $P$. arenosus by L. Fischer $\&$ Th. Glatzel, in prep.). H. K. Schminke (unpubl.) has many more species of this group in his collection that prove this expectation to be well founded. What remains to be solved is the question, which of these characters are autapomorphies of the group of species under discussion here, and not characters defining more inclusive groups. Since a reconstruction of the phylogenetic relationships within Parastenocarididae is as yet impossible, this question is difficult to answer. It can be assumed, though, that the powerful "pocket-knife" formed by segments 5 and 7 of the male antennule (fig. 1D) constitutes such an autapomorphy. Nothing of that kind is known from other species of the family. Leg 5 may be another such autapomorphy, and perhaps also the setation of the furca. Because of the specific structure of the male antennule, the group here under discussion is regarded as monophyletic.

In Jakobi's (1972) system, the type species of two genera belong to the group of species discussed here. They are Kinnecaris Jakobi, 1972 with the type species $K$. forficulata and Cafferocaris Jakobi, 1972 with the type species C. caffer. Since in Jakobi (1972) Kinnecaris is listed first, it is proposed to synonymize Cafferocaris with Kinnecaris, which is a valid and monophyletic taxon on the generic level. The characters defining this phylogenetic entity are, however, quite different from those given by Jakobi (1972). The generic diagnosis, therefore has to be completely revised. The new diagnosis is as follows:

Kinnecaris Jakobi, 1972

Revised generic diagnosis. - Body with pitted cuticle. Latero-ventral integumental windows present on urosomal somites 4 and 5. Two rows of spinules present on urosomal somite 3 of the male. Furcal rami with lateral group of 3 setae located at $2 / 3$ of ramus' length, dorsal seta also inserted there or even more proximally. Antennules of the male 8-segmented, with much dilated fifth segment and forming with sickle-shaped seventh segment a powerful "pocket-knife". Antennule of female 7-segmented. Exopodal segments 2 and 3 of leg 2 and of leg 4 as well as segment 2 of female leg 3 with longitudinal rows of spinules along outer border. Exopod of male leg 3 with two rows of spinules along outer border. Basis of male leg 4 with a row of spinules above insertion of endopod. Leg 5 plate-like and triangular, with long posteriorly-extended, outwardly-curved, spiniform process; apart from basal outer seta with three setae, of which the middle one is the longest; inner border without spinules.

Type species: Kinnecaris forficulata (Chappuis, 1952). 
Other species: K. aethiopica (Cottarelli \& Bruno, 1995) comb. n., K. arenicola (Chappuis, 1954), K. arenosus (Fryer, 1956) comb. n., K. caffer (Chappuis, 1936) comb. n., K. cornuta (Chappuis, 1955) comb. n., K. eberhardi (Karanovic, 2005) comb. n., K. fluviatilis (Wells, 1964) comb. n., K. giselae sp. n., K. impervia (Cottarelli \& Bruno, 1995) comb. n., K. lyncaea (Cottarelli \& Bruno, 1994) comb. n., K. madagascarensis (Chappuis, 1952) comb. n., K. muscicola (Chappuis, 1936) comb. n., K. quollensis (Cottarelli \& Bruno, 1995) comb. n., K. sinoiaica (Wells, 1964) comb. n., K. solitaria (Karanovic, 2004) comb. n., K. variolata (Chappuis, 1952) comb. n. A species to be added shortly is a new species that has been found in India (Ranga Reddy \& Schminke, submitted).

Apart from C. muscicola, C. caffer, and C. variolata, now transferred to Kinnecaris, the genus Cafferocaris also contained the following species: $C$. crassicaudis (Chappuis, 1955), C. pauliani (Chappuis, 1952), and C. pusillus (Chappuis, 1954). With the dissolution of the genus Cafferocaris these species must be treated as incertae sedis until further revision of Parastenocarididae shows where they belong.

The genus has an interesting distribution, being found all along the eastern side of Africa from Ethiopia (3 species) down to South Africa (H. K. Schminke, unpubl.), in Kenya ( 2 species), the Democratic Republic of Congo (Lake Tanganyika, 1 species), Malawi (1 species), and Zimbabwe (2 species), but also in West Africa (Sierra Leone, 1 species). It is known from Madagascar (3 species), India (1 species), Western Australia (2 species), and Papua New Guinea (1 species).

\section{ACKNOWLEDGEMENTS}

Collecting in Papua New Guinea was made possible by a grant of the Deutsche Forschungsgemeinschaft (German Research Association, Schm 352/6-1). My studies of Parastenocarididae were supported by an "Akademie-Stipendium" granted by the VW-Foundation (Hanover). Dr. Elaine J. Brough (formerly Biology Department, The University of Papua New Guinea, Port Moresby) helped generously in many ways, in particular in the logistics of my collecting trips around Port Moresby. I thank her very much for this help. Iris Zaehle (Oldenburg) is thanked for helping with inking the drawings and Jan Drewes for composing the figure plates.

\section{REFERENCES}

Berera, R. \& V. Cottarelli, 2003. Two new species of interstitial harpacticoids from southern Italy and proposal of a new Parastenocaris species-group. Italian Journal of Zoology, 70: 261 268. 
ChappuIs, P. A., 1937. Weitere subterrane Harpacticoiden aus Jugoslavien. Bulletin de la Société des Sciences de Cluj, Roumanie, 8: 503-532.

— —, 1952. Copépodes Harpacticoïdes psammiques de Madagascar. Mémoires de l'Institut Scientifique de Madagascar, (A) 7: 145-160.

_ _, 1954. Recherches sur la faune interstitielle des sédiments marins et d'eau douce de Madagascar. IV. Copépodes Harpacticoïdes psammiques de Madagascar. Mémoires de l'Institut Scientifique de Madagascar, (A) 9: 45-73.

Corgosinho, P. H. C. \& P. Martínez Arbizu, 2005. Two new interstitial species of Remaneicaris Jakobi, 1972 from the Ribeirao do Ouro River, Minais Gerais, Brazil, with redefinition of the genus (Crustacea, Copepoda, Harpacticoida, Parastenocarididae). Senckenbergiana Biologica, 85: 147-162.

Cottarelli, V. \& M. C. Bruno, 1994. Parastenocaris lyncaea n. sp. and Stygoelaphoidella africana n. sp. (Crustacea, Harpacticoida) from interstitial continental waters of Sierra Leone. Quaderno Accademia Nazionale dei Lincei, 267: 97-109.

FRYER, G., 1956. New species of cyclopoid and harpacticoid copepods from sandy beaches of Lake Nyasa. Annals and Magazine of Natural History, (12) 9: 225-249.

Galassi, D. M. P. \& P. De Laurentis, 2004. Towards a revision of the genus Parastenocaris Kessler, 1913: establishment of Simplicaris gen. nov. from groundwaters in Italy and review of the P. brevipes-group (Copepoda, Harpacticoida, Parastenocarididae). Zoological Journal of the Linnean Society, 140: 417-436.

JAKOBI, H., 1972. Trends (Enp P4 $\sigma^{7}$ ) innerhalb der Parastenocarididen (Copepoda Harpacticoidea). Crustaceana, 22: 127-146.

Karanovic, T., 2004. Subterranean Copepoda from arid Western Australia. Crustaceana Monographs, 3: i-viii, 1-366. (Koninklijke Brill, Leiden).

_ _, 2005. Two new subterranean Parastenocarididae (Crustacea, Copepoda, Harpacticoida) from Western Australia. Records of the Western Australian Museum, 22: 353-374.

KUnZ, H., 1938. Harpacticoiden vom Sandstrand der Kurischen Nehrung. Kieler Meeresforschung, 3: $148-157$.

LANG, K., 1948. Monographie der Harpacticiden: 1-1683. (Reprint (1975), Otto Koeltz Science Publishers, Koenigstein).

NoodT, W., 1962. Limnisch-subterrane Copepoden der Gattung Parastenocaris Kessler aus Mittelamerika. Beiträge zur Neotropischen Fauna, 11: 223-248.

— _, 1963. Subterrane Crustaceen der zentralen Neotropis. Zoologischer Anzeiger, 171: 114-147.

_ _, 1972. Drei neue Parastenocaris aus Kolumbien (Crustacea, Copepoda). 1. Mitteilung über kolumbianische Grundwasser-Crustaceen. Studies of the Neotropical Fauna, 7: 101-112.

RANGA REDDY, Y. \& H. K. SCHMINKE, in press. Discovery of the genus Kinnecaris Jakobi, 1972 (Copepoda, Harpacticoida, Parastenocarididae) in southeastern India, with description of a new species. Crustaceana.

REID, J. W., 1995. Redescription of Parastenocaris brevipes Kessler and description of a new species of Parastenocaris (Copepoda: Harpacticoida: Parastenocarididae) from the U.S.A. Canadian Journal of Zoology, 73: 173-187.

Schminke, H. K., 1971. Zwei neue Parastenocaris-Arten (Copepoda, Harpacticoidea) von Tenerife (Kanarische Inseln). Gewässer und Abwässer, 50/51: 66-75.

—, 1986. The systematic confusion within the family Parastenocarididae (Copepoda, Harpacticoida). Syllogeus, 58: 635. [Abstract.]

First received 17 May 2008.

Final version accepted 20 May 2008. 